\title{
Application of beta zeolite in allylation reaction aiming formation of new C-C bonds
}

\author{
(Aplicação de zeólita beta na catálise da reação de \\ alilação visando formação de novas ligações $C$-C)
}

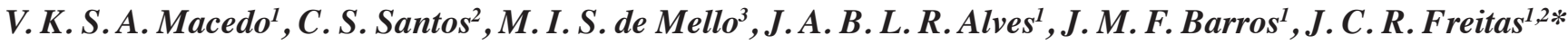 \\ ${ }^{1}$ Universidade Federal de Campina Grande, Centro de Educação e Saúde, Programa de Pós-Graduação em \\ Ciências da Natureza e Biotecnologia, Sítio Olho D'agua da Bica s/n, 58175000, Cuité, PB, Brazil \\ ${ }^{2}$ Universidade Federal Rural de Pernambuco, Departamento de Química, \\ Programa de Pós-Graduação em Química, 52171900, Recife, PE, Brazil \\ ${ }^{3}$ Universidade Federal do Rio Grande do Norte, Instituto de Química, \\ Programa de Pós-Graduação em Química, 59078-970, Natal, RN, Brazil
}

\begin{abstract}
This study describes the formation of new $\mathrm{C}-\mathrm{C}$ bonds through the allylation reaction of different aldehydes promoted by beta zeolite. This environmentally friendly method was characterized by its efficiency, versatility, and chemoselectivity in the formation of different homoallylic alcohols. Homoallylic alcohols were obtained in good yields (80\% to 96\%), short reaction times (30 to 75 $\mathrm{min}$ ) at room temperature, and without the need for additional purifications. In addition, water was used as a co-solvent, ensuring the method a development in the field of green chemistry. Moreover, it was found that the zeolite beta can be reused for up to one reaction cycle without loss of its efficiency.
\end{abstract}

Keywords: chemical catalysis, allylation reaction, homoallylic alcohols, beta zeolite.

Resumo

Este estudo descreve a formação de novas ligações $C$-C através da reação de alilação de diferentes aldeídos promovida pela zeólita beta. Este método ecologicamente amigável foi caracterizado por sua eficiência, versatilidade e quimiosseletividade, na formação de diferentes álcoois homoalílicos. Os álcoois homoalílicos foram obtidos em bons rendimentos (80\% a 96\%), tempos reacionais curtos (30 a $75 \mathrm{~min}$ ) em temperatura ambiente e sem a necessidade de purificações adicionais. Além disso, foi utilizada água como cossolvente garantindo ao método um desenvolvimento no âmbito da química verde. Adicionalmente, constatou-se que a zeólita beta pode ser reutilizada por até um ciclo reacional sem perda de sua eficiência.

Palavras-chave: catálise química, reação de alilação, álcoois homoalílicos, zeólita beta.

\section{INTRODUCTION}

Currently, the term zeolite is used to define any silicabased crystalline microporous solid where a silicon atom can be replaced by other elements (designated $\mathrm{T}$ ) which may be trivalent $\left(\mathrm{Al}^{3+}, \mathrm{Fe}^{3+}, \mathrm{B}^{3+}, \mathrm{Ga}^{3+}\right.$, among others) or tetravalent $\left(\mathrm{Ge}^{4+}, \mathrm{Ti}^{4+}\right.$, among others) [1]. Zeolites have a high specific surface area $\left(350-450 \mathrm{~m}^{2} \cdot \mathrm{g}^{-1}\right)$, high thermal stability, ion exchange capacity, and because they have a defined system of micropores and channels allow reactions to occur selectively allowing distinguishing reagents, products, and transition states on the molecular scale [2-4]. It is noteworthy that zeolites can act as Bronsted acid or Lewis acid, which broadens their applications in the industrial sector [5-7]. Among the various types of microporous

*julianocrufino@pq.cnpq.br

Dhttps://orcid.org/0000-0003-4617-4084 materials, beta zeolite stands out industrially as it is used in the petrochemical industry and fine chemistry as catalysts, sorbents, or ion exchangers $[8,9]$.

Due to the peculiarities of zeolites, they have been used in numerous organic reactions, citing cycloaddition reactions, multicomponent reactions, and coupling reactions [6]. From a synthetic chemistry standpoint, such reactions are critical as they enable the formation of new carbon-carbon (C-C) bonds, allowing access to various natural products and biologically active compounds $[10,11]$. It is noteworthy that among the various methodologies aimed at the formation of new C-C bonds, one that deserves attention is based on the addition of allylic organometallic species to carbonyl compounds, this reaction is called allylation $[12,13]$. The products of the allylation reaction are homoallylic alcohols, important building blocks applied in the synthesis of numerous natural and synthetic products [14], citing goniothalamin [15, 16], epothilone D [17], macrolactin F [18, 19], palmerolide A 
[20], achaetolide [21], (-)-tetrahydrolipstatin [22], and $(R)$ rugulactone [23] (Fig. 1).

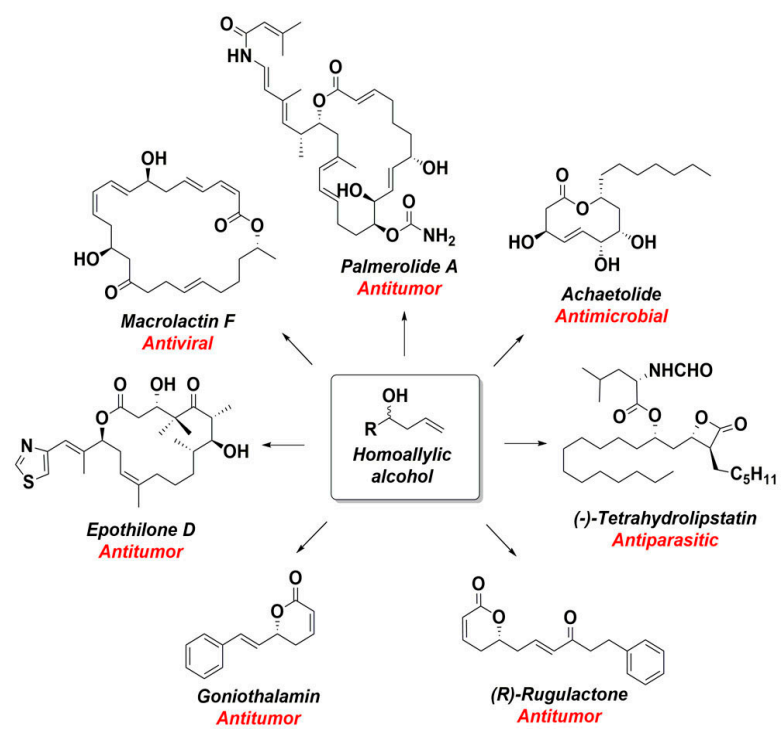

Figure 1. Examples of biologically active molecules obtained from the homoallylic alcohols.

[Figura 1. Exemplos de moléculas biologicamente ativas obtidas a partir dos álcoois homoalílicos.]

Due to the importance of homoallylic alcohols for synthetic chemistry, the literature describes the synthesis of these compounds using different organometallic species, citing the salts of organotrifluoroborates, which were first used in [24]. These salts have numerous advantages over other organometallic species, to cite, they are crystalline solids stable in air and humidity, have low toxicity, and because they are salts, the reactions can be conducted in aqueous medium [25]. Because of these characteristics, these compounds have been widely applied in the allylation reaction, but this reaction requires the use of a catalyst to achieve a reasonable reaction rate, which may be Bronsted or Lewis acids [19, 24, 26-29]. However, most methodologies employ the use of homogeneous catalysts, which in some cases cannot be recovered $[19,24,26]$. Although the use of homogeneous catalysts in the allylation reaction is efficient, this type of catalysis is unattractive to the industry as it implies the increased generation of waste that may be corrosive and toxic in nature, increasing production costs [30], in addition to contrasting the principles of green chemistry [31]. Based on these considerations, this study proposes to develop a fast, efficient, selective, and ecologically acceptable method for the formation of new C-C bonds, through the allylation reaction of different aldehydes by potassium allyltrifluoroborate catalyzed by beta zeolite, considering that there are no reports in the literature of the use of this microporous material in this reaction.

\section{MATERIALS AND METHODS}

Equipment, materials, solvents, and reagents: in general, reagents and solvents from Sigma-Aldrich, Dinâmica, and Cinética suppliers were used. Zeolite beta was purchased from Focus Zeolite, and according to the manufacturer had relative crystallinity of $78 \%$, crystal size of $50 \mathrm{~nm}$, pore volume of $0.3 \mathrm{~mL} \cdot \mathrm{g}^{-1}$, microporous specific surface of $430 \mathrm{~m}^{2} \cdot \mathrm{g}^{-1}$, surface area of $500 \mathrm{~m}^{2} \cdot \mathrm{g}^{-1}$, and silica/alumina ratio of $23 \%$. The solvents were purified by the Perrin and Armarego protocol [32], where hexane and ethyl acetate (AcOEt) were distilled separately by a Vigreux column, while dichloromethane (DCM) was distilled under calcium chloride. The reaction was monitored by a thin layer chromatography (CCD) and visualized by ultraviolet light with a wavelength of $254 \mathrm{~nm}$. For the reuse of beta zeolite, a Centribio 80-2B centrifuge was used to decant beta zeolite and allow the removal of the supernatant liquid. Nuclear magnetic resonance spectra were recorded with a Varian Unity Plus $300 \mathrm{MHz}$ spectrometer for the hydrogen nucleus and $75 \mathrm{MHz}$ for the carbon nucleus. Chemical shifts were expressed in ppm (parts per million) relative to the residual chloroform peak $(7.26 \mathrm{ppm})$ for hydrogen spectra and relative to the $\mathrm{CDCl}_{3}$ central peak $(77.0 \mathrm{ppm})$ for carbon spectra. All coupling constants $(J)$ were described in hertz $(\mathrm{Hz})$.

Experimental procedure. General procedure for the allylation of aldehydes (1 $\mathbf{a}-\boldsymbol{k})$ with potassium allyltrifluoroborate (2) using beta zeolite: in a test tube containing the appropriate aldehyde (1a-k, $0.25 \mathrm{mmol}$ ) dissolved in DCM $(2.25 \mathrm{~mL})$ was added to the beta zeolite $(100 \% \mathrm{~m} / \mathrm{m})$, potassium allyltrifluoroborate $(2,49 \mathrm{mg}, 0.3$ $\mathrm{mmol})$, and water $(0.25 \mathrm{~mL})$. The biphasic system was left under vigorous stirring, and the termination of the reaction was monitored by a thin layer chromatography (TLC) using a hexane:ethyl acetate (7:3) mixture as eluent. After completion of the reaction, ethyl acetate $(20 \mathrm{~mL})$ was added, and the resulting organic phase separated. The organic phase was washed with saturated potassium bicarbonate solution $(3 \times 20 \mathrm{~mL})$ and then with a saturated sodium chloride solution $(20 \mathrm{~mL})$. The organic phase was separated, dried over anhydrous $\mathrm{MgSO}_{4}$, and the solvent reduced by rotary evaporation under reduced pressure leading to homoallylic alcohols 3a-k without further purification.

General procedure for the recycling of beta zeolite: initially, the reaction was performed as described in the previous procedure and, after completion of the reaction, the test tube was centrifuged for $10 \mathrm{~min}$ at a rotation of 2500 rpm. After this time, the tube was carefully removed from the centrifuge, and the supernatant liquid was removed with the aid of a Pasteur pipette. Then DCM $(2.0 \mathrm{~mL})$ was added to the test tube and centrifuged for a further 10 min followed by removal of the organic phase. This last procedure was repeated 3 times to ensure a more efficient wash of beta zeolite. After this wash, beta zeolite was reused for further reaction cycles.

Surface acidity measures of beta zeolite: the total acidity of beta zeolite was determined by the base adsorption method followed by desorption by increasing the temperature using a thermogravimetric scale model Mettler Toledo TGA/SDTA 
851. The base used as a probe molecule was $n$-butylamine. The procedure consisted, initially, of heating from 25 to $400{ }^{\circ} \mathrm{C}$ the beta zeolite already calcined, for the activation of the acidic sites, under a flow of $\mathrm{N}_{2}$ of $30 \mathrm{~mL} \cdot \mathrm{min}^{-1}$ for $40 \mathrm{~min}$. After this period, the temperature was reduced to $95{ }^{\circ} \mathrm{C}$, and the $n$-butylamine vapors were continuously directed to the beta zeolite by the flow of $\mathrm{N}_{2}$ for $1 \mathrm{~h}$, for complete saturation of the acidic sites present in the material. Then, the saturated beta zeolite was purified with pure $\mathrm{N}_{2}$ at the same saturation temperature for $30 \mathrm{~min}$ to remove the physically adsorbed base. After this treatment, $n$-butylamine thermosorption was performed in a thermobalance at a heating rate of $10^{\circ} \mathrm{C} \cdot \mathrm{min}^{-1}$, from 30 to $900{ }^{\circ} \mathrm{C}$, under a nitrogen flow of $25 \mathrm{~mL} \cdot \mathrm{min}^{-1}$. Total acidity was calculated as a function of the amount of thermosorbed $n$-butylamine.

\section{RESULTS AND DISCUSSION}

Although the literature describes some methods for the synthesis of potassium allyltrifluoroborate (2) [33, 34], it was decided to obtain it commercially. Thus, the study was started by evaluating the influence of the proportion of solvents on the allylation reaction of $p$-nitrobenzaldehyde (1a) by potassium allyltrifluoroborate (2) keeping the amount of beta zeolite set at $100 \% \mathrm{~m} / \mathrm{m}$. The results are presented in Table I, and all reported yields in this and other tables are isolated yields. When only $\mathrm{CH}_{2} \mathrm{Cl}_{2}$ was used as the reaction solvent, homoallylic alcohol $\mathbf{3 a}$ was obtained in low yield, possibly due to the low solubility of compound $\mathbf{2}$ in this solvent (experiment 5). A similar result was described by Barbosa et al. [19], where they obtained the same compound with a $15 \%$ yield after 15 min using a homogeneous catalyst. However, when only $\mathrm{H}_{2} \mathrm{O}$ was used as the reaction solvent, the product of interest $\mathbf{3 a}$ was obtained

Table I - Effect of $\mathrm{H}_{2} \mathrm{O}: \mathrm{CH}_{2} \mathrm{Cl}_{2}$ ratio on the allylation of $p$-nitrobenzaldehyde (1a) by potassium allyltrifluoroborate (2) at room temperature.

[Tabela I - Efeito da proporção de $\mathrm{H}_{2} \mathrm{O}: \mathrm{CH}_{2} \mathrm{Cl}_{2}$ na alilação do p-nitrobenzaldeído (1a) pelo aliltrifluoroborato de potássio (2) em temperatura ambiente.]

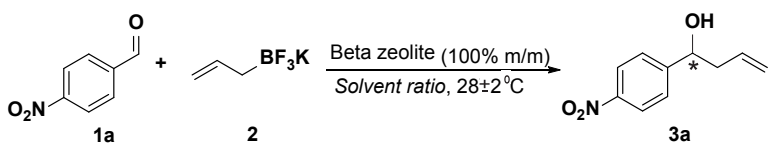

\begin{tabular}{cccc}
\hline Experiment $^{\mathrm{a}}$ & $\begin{array}{c}\text { Ratio } \\
\mathrm{H}_{2} \mathrm{O}: \mathrm{CH}_{2} \mathrm{Cl}_{2}\end{array}$ & $\begin{array}{c}\text { Time } \\
(\mathrm{min})\end{array}$ & $\begin{array}{c}\text { Yield }^{\mathrm{b}} \\
(\%)\end{array}$ \\
\hline 1 & $2.5 \mathrm{~mL}: 0 \mathrm{~mL}$ & 30 & 81 \\
2 & $2.25 \mathrm{~mL}: 0.25 \mathrm{~mL}$ & 30 & 84 \\
3 & $1.25 \mathrm{~mL}: 1.25 \mathrm{~mL}$ & 30 & 90 \\
4 & $0.25 \mathrm{~mL}: 2.25 \mathrm{~mL}$ & 30 & 95 \\
5 & $0 \mathrm{~mL}: 2.5 \mathrm{~mL}$ & 30 & $69^{\mathrm{c}}$ \\
\hline
\end{tabular}

a experiment was performed using 0.25 mmol of compound 1 a, 0.30 mmol of compound 2 , and $100 \% \mathrm{~m} / \mathrm{m}$ of zeolite beta relative to compound $1 \mathrm{a} ;{ }^{b}$ yield of isolated products; ${ }^{c}$ incomplete reaction.
Table II - Effect of beta zeolite amount on the allylation of $p$-nitrobenzaldehyde (1a) by potassium allyltrifluoroborate (2) in 10:90 $\mathrm{H}_{2} \mathrm{O}: \mathrm{CH}_{2} \mathrm{Cl}_{2}$ at room temperature.

[Tabela II - Efeito da quantidade de zeólita beta na alilação do p-nitrobenzaldeído (1a) pelo aliltrifluoroborato de potássio (2) em 10:90 $\mathrm{H}_{2} \mathrm{O}: \mathrm{CH}_{2} \mathrm{Cl}_{2}$ em temperatura ambiente.]

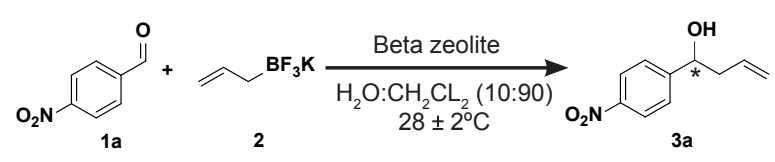

\begin{tabular}{cccc}
\hline Experiment $^{\mathrm{a}}$ & $\begin{array}{c}\text { Beta zeolite } \\
(\% \mathrm{~m} / \mathrm{m})\end{array}$ & $\begin{array}{c}\text { Time } \\
(\mathrm{min})\end{array}$ & $\begin{array}{c}\text { Yield }^{\mathrm{b}} \\
(\%)\end{array}$ \\
\hline 1 & 150 & 30 & $80^{\mathrm{c}}$ \\
2 & 100 & 30 & 95 \\
3 & 75 & 30 & 94 \\
4 & 50 & 40 & 91 \\
5 & 25 & 60 & $60^{\mathrm{c}}$ \\
6 & $-{ }^{\mathrm{c}}$ & 60 & $29^{\mathrm{c}}$ \\
\hline
\end{tabular}

a experiment was performed using 0.25 mmol of compound 1 a, $0.30 \mathrm{mmol}$ of compound 2 , and different amounts of zeolite beta with respect to compound $1 a ;^{b}$ yield of isolated products; ${ }^{c}$ incomplete reaction.

in better yield (experiment 1). Despite the good result of the reaction in the aqueous medium, it was decided to use a biphasic system $\left(\mathrm{H}_{2} \mathrm{O}: \mathrm{CH}_{2} \mathrm{Cl}_{2}\right.$ in the ratio $0.25 \mathrm{~mL}: 2.25$ $\mathrm{mL}$ ), due to the considered increase in yield (95\%) and due to some aldehydes being insoluble in water (experiment 4). Additionally, Farias et al. [35] described that the allylation of $p$-bromobenzaldehyde by potassium allyltrifluoroborate in the salicylic acid-catalyzed aqueous medium did not lead to the formation of 1-(4-bromophenyl)but-3-en-1-ol.

Since the biphasic $\mathrm{H}_{2} \mathrm{O}: \mathrm{CH}_{2} \mathrm{Cl}_{2}$ system (ratio 0.25 $\mathrm{mL}: 2.25 \mathrm{~mL}$ ) led to the best result, it was started to study the influence of the required amount of beta zeolite to be employed in the allylation reaction of the compound 1a. The results are presented in Table II. When $100 \%$ and $75 \% \mathrm{~m} / \mathrm{m}$ beta zeolite was used, homoallylic alcohol 3a was obtained in excellent yields (experiments 2 and 3). However, a drastic increase in the amount of beta zeolite to $150 \% \mathrm{~m} / \mathrm{m}$ led to a decrease in yield (experiment 1), and by-products were visualized by $C C D$, probably due to the increase in acidity, since the thermogravimetric curves of beta zeolite, showing

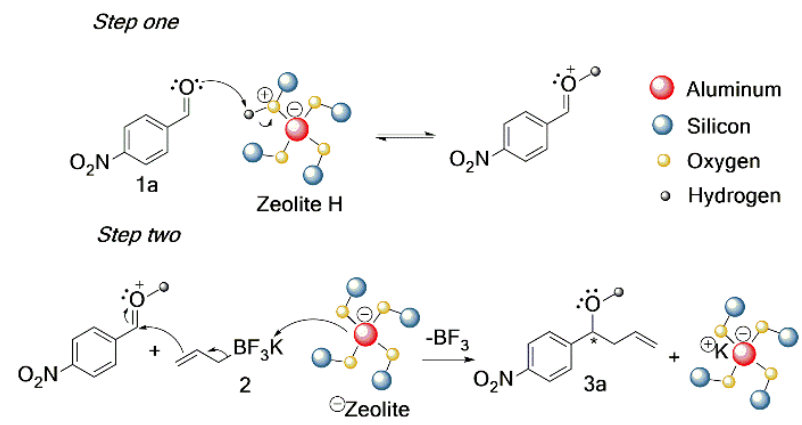

Figure 2. Mechanistic proposal of the allylation reaction. [Figura 2. Proposta mecanística da reação de alilação.] 
Table III - Allylation of different aldehydes (1a-l) with potassium allyltrifluoroborate (2) catalyzed by beta zeolite $(100 \% \mathrm{~m} / \mathrm{m})$. [Tabela III - Alilação de diferente aldeídos (1a-l) por aliltrifluoroborato de potássio (2) catalisada pela zeólita beta $(100 \% \mathrm{~m} / \mathrm{m})$.]

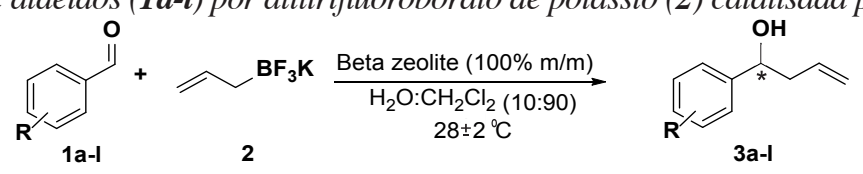

\begin{tabular}{|c|c|c|c|c|c|c|}
\hline Experiment & Aldehyde & & Product & & Time (min) & Yield $^{\mathrm{a}}(\%)$ \\
\hline 1 & & $1 \mathbf{a}$ & & $3 \mathbf{a}$ & 30 & 95 \\
\hline 2 & & $1 \mathrm{~b}$ & & $3 b$ & 30 & 91 \\
\hline 3 & & $1 c$ & & $3 c$ & 30 & 94 \\
\hline 4 & & 1d & & 3d & 45 & 89 \\
\hline 5 & & 1e & & $3 \mathbf{e}$ & 50 & 92 \\
\hline 6 & & 1f & & $3 f$ & 75 & 96 \\
\hline 7 & & $1 \mathrm{~g}$ & & $3 g$ & 40 & 91 \\
\hline 8 & & $1 \mathrm{~h}$ & & $3 h$ & 40 & 92 \\
\hline 9 & & $1 \mathbf{i}$ & & $3 \mathbf{i}$ & 40 & 89 \\
\hline 10 & & $1 \mathrm{j}$ & & $\mathbf{3 j}$ & 60 & 91 \\
\hline 11 & & $1 k$ & & $3 k$ & 75 & 92 \\
\hline 12 & & 11 & & 31 & 60 & 80 \\
\hline
\end{tabular}

aield of isolated products.

the thermal desorption of the $n$-butylamine molecule, indicated an acidity of $2.6 \mathrm{mmol} . \mathrm{g}^{-1}$. A similar result was described by Couto et al. [36] when they increased the
Amberlyst A-15 the reaction yield decreased. When the amount of beta zeolite was drastically reduced to $25 \% \mathrm{~m} / \mathrm{m}$, the reaction was not complete (experiment 5), even leaving 
Table IV - Spectroscopic characterization of the homoallylic alcohols 3a-l.

[Tabela IV - Caracterização espectroscópica dos álcoois homoalílicos 3a-l.]

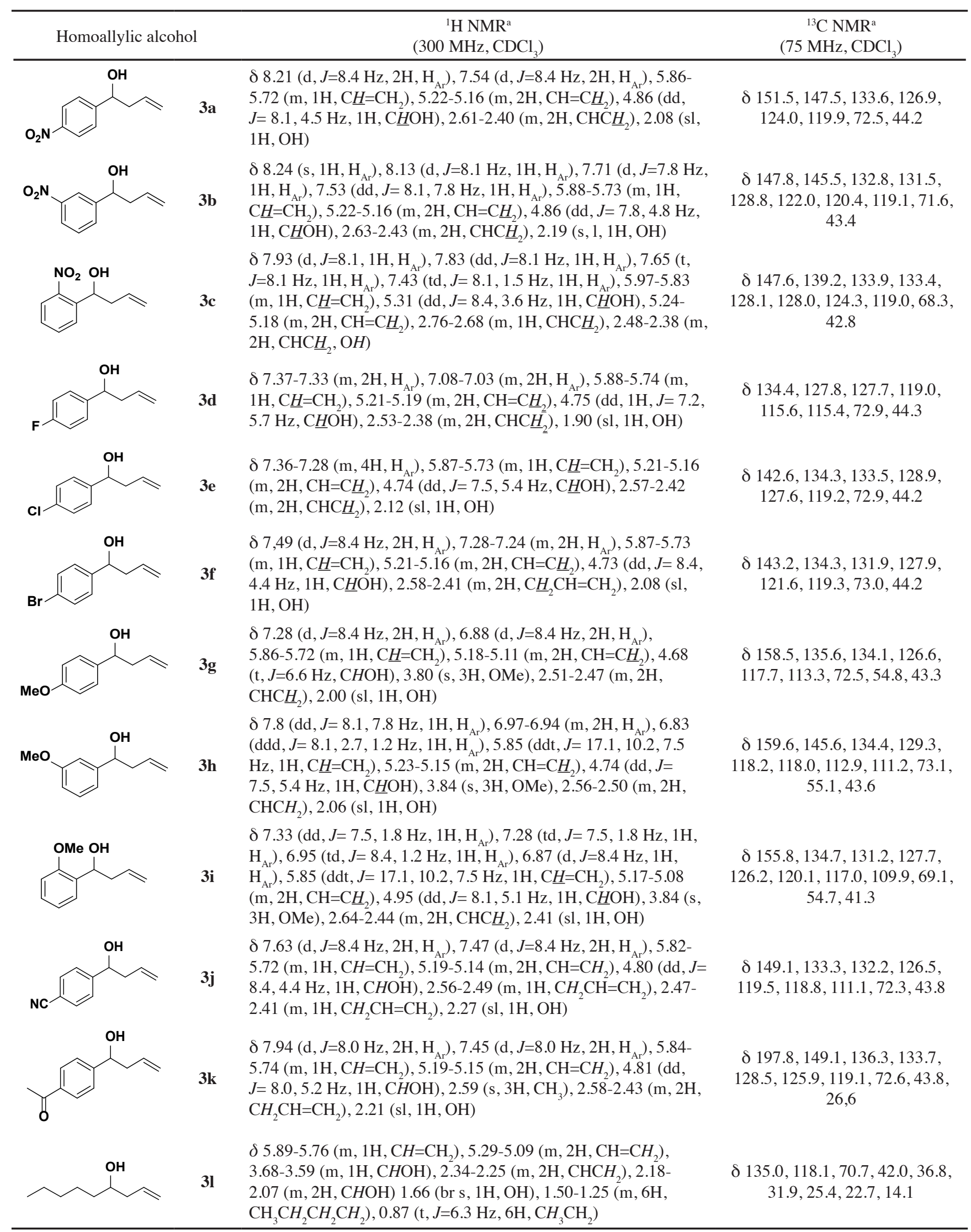

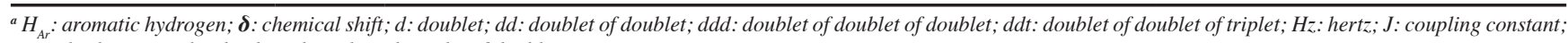
m: multiplet; s: singlet; bs: broad singlet; td: triplet of doublet. 
the reaction system for up to $60 \mathrm{~min}$. It was found that the reaction requires beta zeolite since the yield obtained in its absence was very low (experiment 6). A likely mechanism for this allylation reaction (Fig. 2) is initially based on the protonation of carbonyl of compound 1a by beta zeolite making carbonyl carbon more electrophilic, followed by the attack of allyl grouping of compound 2 leading to homoallylic alcohol 3a.

After optimizing the reaction conditions for synthesis homoallylic alcohol 3a, the next step was to evaluate the robustness of the method using different aldehydes. The results are presented in Table III, which shows that the allylation reaction using beta zeolite tolerates different types of aromatic and aliphatic aldehydes, since the products were obtained in yields ranging from good to excellent. When $o-$, $m$-, and $p$-nitrobenzaldehyde 1a-c were used, it was found that there was no variation in reaction time, and the products were obtained with similar yields (experiments 1 and 3), allowing to conjecture that the steric hindrance does not affect this reaction. The same was observed for allylation using aldehydes containing the methoxy group at the $o^{-}, \mathrm{m}^{-}$, and $p$ - positions (experiments 7 and 9). It is noteworthy that Couto et al. [36] when performing the allylation reaction using the Amberlyst A-15, found that the position of electron-withdrawing or electron-donating groups did not significantly affect the reaction time and yield. However, methoxybenzaldehyde allylations $\mathbf{1 g}$-i had a longer reaction time compared to nitrobenzaldehyde allylations 1a-c, most likely due to the methoxy group being electron donor, which makes carbonyl less electrophilic, making nucleophilic attack difficult.

The influence of weakly activating groups can also be seen in Table III, where the allylation of halogen-containing aromatic aldehydes led to the respective homoallylic alcohols (3d-f) in excellent yields (experiments 4, 5, and 6). It was observed that the increased electronegativity of the halogen present in the ring contributed significantly to a reduction in reaction time, which is justifiable, since these groups inductively deactivate the ring, making carbonyl more electrophilic and susceptible to nucleophile attack. The reaction appears to be chemoselective because only

Table V - Beta zeolite $(100 \% \mathrm{~m} / \mathrm{m})$ recycling after successive reactions of allylation.

[Tabela V - Reciclagem de zeólita beta $(100 \% \mathrm{~m} / \mathrm{m})$ após sucessivas reações de alilação.]

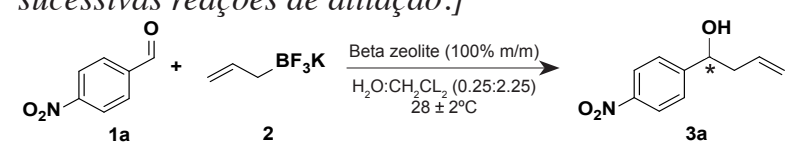

\begin{tabular}{cccc}
\hline Experiment & Cycle & Time (min) & Yield (\%) \\
\hline 1 & - & 30 & 95 \\
2 & 1 & 40 & 91 \\
3 & 2 & 90 & $51^{\mathrm{a}}$ \\
4 & 3 & 90 & $45^{\mathrm{a}}$ \\
\hline
\end{tabular}

${ }^{a}$ incomplete reaction. addition was observed in aldehyde carbonyl (experiments 10 and 11). Regarding the allylation of aliphatic aldehydes, the homoallylic alcohol $\mathbf{3 l}$ was obtained after $60 \mathrm{~min}$ in moderate yield. Homoallylic alcohols 3a-i were characterized by the usual spectroscopic techniques $\left({ }^{1} \mathrm{H}\right.$ and ${ }^{13} \mathrm{C}$ NMR), as summarized in Table IV.

As beta zeolite proved to be efficient in the allylation reaction catalysis, a study of the recyclability of this material was carried out. The results are presented in Table V; it can be seen that the reuse of beta zeolite was able to efficiently promote the allylation reaction through a reaction cycle (experiment 2). After the first reuse cycle of beta zeolite, there was an increase in reaction time from 30 to $40 \mathrm{~min}$. From the second and third reuse cycle, the yields of the obtained products were around $51 \%$ and $45 \%$, respectively, and the reaction times remained at $90 \mathrm{~min}$. Overall, these results were very satisfactory as beta zeolite promoted the allylation reaction in short reaction time, and, in addition, an excellent yield was obtained until the first reaction cycle.

\section{CONCLUSIONS}

The developed method proved to be fast, efficient, and robust, presenting itself as an alternative to the existing methods in the literature aiming for the formation of new $\mathrm{C}-\mathrm{C}$ bonds. The allylation reaction of different aldehydes using beta zeolite was chemoselective and homoallylic alcohols were obtained in yields ranging from good to excellent ( $80 \%$ to $96 \%$ ). Beta zeolite has been shown to be a stable heterogeneous promoter in the $\mathrm{H}_{2} \mathrm{O}: \mathrm{CH}_{2} \mathrm{Cl}_{2}$ system, and is easily manipulated and removed from the reaction medium, resulting in a decrease in the generated residues. It is also worth mentioning that in this method, water was used as a co-solvent, making it environmentally friendly and more economically viable.

\section{ACKNOWLEDGMENTS}

The authors acknowledge CNPq (434012/2018-1) and PRONEM/FACEPE (APQ-0476-1.06/14) for their financial support, CAPES for the scholarships granted, and Analytical Center of the Federal University of Pernambuco for analyzes of spectroscopy of the compounds.

\section{REFERENCES}

[1] Y.X. Tan, F. Wang, J. Zhang, Chem. Soc. Rev. 47 (2018) 2130.

[2] Y. Li, L. Li, J. Yu, Chem 3 (2017) 928.

[3] A.F. Guzik, Microporous Mesoporous Mater. 259 (2018) 33.

[4] K.A. Sashkina, N.A. Rudina, A.B. Ayupova, E.V. Parkhomchuk, Mater. Today Proc. 4 (2017) 11418.

[5] V. Verdoliva, M. Saviano, S. De Luca, Catalysts 9 (2019) 248.

[6] B. Sarmah, B. Satpati, R.J. Srivastava, J. Colloid Interface Sci. 493 (2017) 307. 
[7] T.R.D. Mendonça, J.R. Santos, L.R.A. Sarmento, D.C.M. Silva, O.M.S. Cysneiros, A.O.S. Silva, Cerâmica 65, 375 (2019) 378.

[8] S. Fernandez, M.L. Ostraat, J.A. Lawrence, K. Zhang, Microporous Mesoporous Mater. 263 (2018) 201.

[9] G. Xiong, X. Liu, R. Zhao, J. Liu, J. Yin, Q. Meng, Z. Guo, L. Liu, Microporous Mesoporous Mater. 249 (2017) 97.

[10] D. Andrade, J.R. Freitas, J.C.R. Freitas, Quím. Nova 39 (2016) 1225.

[11] S. Gao, H. Lin, Z. Wu, H. Yao, A. Lin, Green Chem. 19 (2017) 1861.

[12] N.K. Mishra, S. Sharma, J. Park, S. Han, I.S. Kim, ACS Catal. 7 (2017) 2821.

[13] Y. Chu, Q. Pu, Z. Tang, L. Gao, Z. Song, Tetrahedron 73 (2017) 3707.

[14] S. Nakamura, Y. Hara, T. Furukawa, T. Hirashira, RSC Adv. 7 (2017) 15582.

[15] P. Harsh, G.A. O’Doherty, Tetrahedron 65 (2009) 5051. [16] A. Fátima, L.K. Kohn, J.E. Carvalho, R.A. Pilli, Bioorg. Med. Chem. 14 (2006) 622.

[17] A.J. Hurski, N.A. Sokolov, O.G. Kulinkovich, Tetrahedron 65 (2009) 3518.

[18] R.A. Oliveira, J.M. Oliveira, L.H.S. Rahmeier, J.V. Comasseto, J.P. Marino, P.H. Menezes, Tetrahedron Lett. 49 (2008) 5759.

[19] F.C.G. Barbosa, J.C.R. Freitas, C.F. Melo, P.H. Menezes, R.A. Oliveira, Molecules 17 (2012) 14099.

[20] K. Nicolaou, G.Y. Leung, D.H. Dethe, R. Guduru, Y.P. Sun, C.S. Lim, D.Y.K. Chen, J. Am. Chem. Soc. 130 (2008) 10019.

[21] P. Srihari, B. Kumaraswamy, P. Shankar, V.
Ravishashidhar, J. Yadav, Tetrahedron Lett. 51 (2010) 6174. [22] A.N. Thadani, R.A. Batey, Tetrahedron Lett. 44 (2003) 8051.

[23] D.K. Reddy, V. Shekhar, T.S. Reddy, S.P. Reddy, Y. Venkateswarlu, Tetrahedron Asymmetry 20 (2009) 2315.

[24] R.A. Batey, A.N. Thadani, D.V. Smil, Tetrahedron Lett. 40 (1999) 4289.

[25] G.A. Molander, J. Org. Chem. 80 (2015) 7837.

[26] H. Matsuoka, K. Kondo, Tetrahedron Lett. 50 (2009) 2320.

[27] F. Nowrouzi, A.N. Thadani, R.A. Batey, Org. Lett. 11 (2009) 2631.

[28] A.N. Thadani, R.A. Batey, Org. Lett. 4 (2002) 3827.

[29] H. Nakamura, K. Shimizu, Tetrahedron Lett. 52 (2011) 426.

[30] G.T. Pawar, S.P. Gadekar, B.R. Arbad, M.K. Lander, Bull. Chem. React. Eng. Catal. 12 (2017) 32.

[31] J.E. Lenardão, R.A. Freitas, M.J. Dabdoub, F.C.A. Batista, C.C. Silveira, Quím. Nova 26 (2003) 123.

[32] D.D. Perrin, W.L.F. Amarego, Purification of laboratory chemicals, $3^{\text {rd }}$ ed., Pergamon Press, Oxford (1996).

[33] R.A. Batey, A.N. Thadani, D.V. Smil, A.J. Lough, Synthesis 2000 (2000) 990.

[34] J.J.R. Freitas, T.R. Couto, I.H. Cavalcanti, J.C.R. Freitas, R.A. Oliveira, P.H. Menezes, Ultrason. Sonochem. 21 (2014) 1609.

[35] J.F. Silva, J.A.C. Lima, J.J.R. Freitas, L.P.S.R. Freitas, P.H. Menezes, J.C.R. Freitas, Lett. Org. Chem. 13 (2016) 49. [36] T.R. Couto, J.C.R. Freitas, I.H. Cavalvanti, R.A. Oliveira, P.H. Menezes, Tetrahedron 69 (2013) 7006.

(Rec. 04/09/2019, Rev. 01/11/2019, 02/02/2020, Ac. $16 / 02 / 2020)$ 